\title{
A LOOK AT RUSSIAN MUSICAL CULTURE IN THE SECOND HALF OF THE XIX CENTURY
}

\section{Azizbek Haydarov}

Senior Teacher, Fergana Regional Branch Of Uzbekistan State Institute Of Arts And Culture, Uzbekistan

\section{ABSTRACT}

This article tells about the activities of Russian composers in the second half of the XIX century, the creative life of Russian music, the work of composers of these years.In the first half of the 19th century, the role of the Russian classical school proved to be important in countries other than Russia.In the second half of the nineteenth century, Russian music became one of the most advanced forms of musical art that determined the further development of European musical art.

KEYWORDS:- Art, culture, theater, music, opera, conductor, composer.

\section{INTRODUCTION}

The second half of the 19th century was an important period for Russian art and cultural life. The month of February 1861 led to a reform that limited legal law, leaving no art form out of the free thought of the people. The 60s were a flourishing period of clear ideas, fine arts, theater, Russian literature.

There have been many changes in the life of Russian music, and music has gained many wideranging fans. In 1859 in St. Petersburg, in 1860 in Moscow the organizing committee of Russian music (RMS-Russian music society) was established. The concerts organized by the Organizing Committee of Russian Music performed works by Russian composers and gave Russian artists the opportunity to participate in concerts.

In 1862 the first Russian conservatory was opened in St. Petersburg. Its director was the famous pianist Anton Grigorevich Rubinstein. In 1866, the Moscow Conservatory was opened, and the brother of its director, Anton Grigorevich, was appointed Nikolai Grigorevich Rubinstein, a highly educated musician, pianist, conductor, and educator. In 1862, the Balakirev Movement opened a free music school.

Composers who were members of the Balakirev circle and Tchaikovsky's work played a key role in the creative life of Russian music. This group of five composers in creative friendship is called 
CURRENT RESEARCH JOURNAL OF PEDAGOGICS 2(11): 24-31, November

2021 DOI: https://doi.org/10.37547/pedagogics-crjp-02-11-08

ISSN 2767-3278

(C)2021 Master Journals

\section{Crossref do) 8 Google}

Accepted 25th November, 2021 \& Published 30 ${ }^{\text {th }}$ November, 2021

the "mighty gang". Its members were Miliy Alekseevich Balakirev, Caesar Kyui, Modest Petrovich Musorgsky, Alexander Pofirevich Borodin, Nikolai Andreevich Rimsky-Korsakov. Their relationship was not only due to the unity and friendship in music lessons, but also to their common musical views, goals and objectives. They were all in contact with Dargomyjsky. VV Stasov was the one who led and inspired the members of the "mighty gang".He is a very humble, interesting, infinitely enthusiastic, highly educated person. Stasov was a music critic, art historian, historian, assistant and friend of many composers and artists, and he was considered a man with a high level of ability, such as all the advances at first sight and foresight.

Stasov was ideologically close to the views of Belinsky and the Revolutionary Democrats. Stasov is of great importance in the national art in the struggle for the people. Stasov lived a long life and was in touch with different generations of Russian musicians. The late nineteenth and early twentieth centuries opposed modernist currents. However, several progressive works of Russian music, such as Tchaikovsky's work and his national character, were incomprehensible to Stasov. The musical creativity of composers such as Serov and Tchaikovsky is associated with folk songs, primarily Russian songs, as well as Ukrainian and other national songs.It has gone through several stages in the development of the 'mighty gang'.

Stage 1 - The formation of the union led by Balakirev.

Stage 2 - The flowering of solidarity in the unity of views, aspirations in the field of art.

Stage 3 is the brilliance of each composer's individual creativity, but, at the creative stage, the weakening of unity.

The "Mighty Gang" was similar to other creative associations of the period: the "Circle of Nomadic Artists" ("Tovarishchestvo peredvijnyx vystavok") as a circle of writers united around the magazine "Sovremennik" ("Contemporary").

The creative individualities of the composers of the "mighty gang" were united by one goal, despite their diversity. The continuation of the work started by Glinka was infinitely connected with folk art. They studied folk songs very well.At the same time, Russian opera was emerging as an innovator in the development of symphonic and chamber music, looking for ways to use and enrich the methods of brilliant demonstration of the new musical language.

Members of the gang and Tchaikovsky's attitude to common folk songs in aesthetics and the development of Russian professional music played an important role in folk art: Balakirev, Rimsky-Korsakov, Tchaikovsky were the authors of collections of folk songs.

In the $60 \mathrm{~s}$ and $70 \mathrm{~s}$, immortal works such as Mussorgsky's "Boris Godunov" and "Khovanshina", Borodin's "Prince Igor", RimskyKorsakov's "Pskovityanka", Tchaikovsky's "Eugene Onegin", four symphonies, Borodin's 1-2 symphonies were created. The creation of Tchaikovsky's ballet Lebedinoe ozero (Swan Lake) in 1876 marked the beginning of the classical period of Russian ballet.

In the 70's, the classical stage began in the concert genre. In 1874 Tchaikovsky wrote his first concerts for piano and orchestra, and in 1878 for violin and orchestra. For the first time, vocal and piano cycles played an important role. The development of the instrumental quartet is also related to the development of the classics of the 70s. Tchaikovsky's first quartet was written in 1871, and Borodin's first quartet in 1879.

In all the many genres of Russian music of the $60 \mathrm{~s}$ and $70 \mathrm{~s}$, the genres of opera, program symphonic music and romance stand out. It is 
CURRENT RESEARCH JOURNAL OF PEDAGOGICS 2(11): 24-31, November

2021 DOI: https://doi.org/10.37547/pedagogics-crjp-02-11-08

ISSN 2767-3278

(C)2021 Master Journals

\section{Crossref do) 8 Google}

Accepted 25th November, 2021 \& Published 30 ${ }^{\text {th }}$ November, 2021

from these genres that the main aesthetic problems of the Osh period are concentrated.

During these years, all forms of opera identified in the works of Glinka and Dargomyjsky developed: historical, epic, lyrical operas.

Mussorgsky's historical operas "Boris Godunov" and "Khovanshchina" were the culmination of the development of the historical genre of the XIX century. Rimsky-Korsakov's opera-drama "Pskovityanka" can also be called a historical opera. Because the personal drama of Olga and King Ivan the Terrible is freely connected with the fate of Pskov. It is written in the tradition of Borodin's historical epic opera "Prince Igor" and Glinka's opera "Ruslan and Lyudmila".

Lyrical opera is distinguished by its great genre and its diversity. AG Rubinstein's opera "Demon" combines a dramatic psychological and domestic structure. Serov's opera Vrajya Sila (The Power of the Enemy) was written for Ostrovsky.It became a unique opera song genre. RimskyKorsakov's opera Mayskaya noch (May Night) is a lyrical and fantastic opera. Mussorgsky's opera Sorochinskaya Yarmarka and Tchaikovsky's Kuznets Vakula are lyrical and humorous. Tchaikovsky's opera Eugene Onegin was the culmination of a lyrical-psychological opera. The melodic recitation of Dargamyzhsky's opera "Stone Guest" based on Pushkin's words became a musical work that influenced the work of later composers.

Program-symphonic music of Russian composers formed a large part of the general European romantic-program music of the middle of the XIX century. These are fantasies, overtures, paintings and symphonic poems. Russian composers incorporated their individuality into the principles of formation, harmony, melody.

During these years two types of symphonic poems developed.

1. Poem as a color image.

\section{Poem as a psychological drama.}

The first is Rimsky-Korsakov's symphonic painting "Sadko", and the second is Tchaikovsky's symphonic works "Fatum", "Romeo and Juliet", "Burya", "Francesco da Rimini".

In the works of composers of these years, romance - song, romance - monologue, romance elegy, ballad, songs are widely used. Satirical and social romances played an important role.Examples include Mussorgsky's Rayok, a sharp satire on the musical life of the time, the tragic ballad "Forgotten", and his cycle "Songs and Games of Death".In his work, various structures of yikls were developed. Among them are "Childhood", the feelings of the children's world, and "Without the sun" poems about loneliness.

Epic romances were also written during this period. Examples are Borodin's "Song of the Dark Forest" and "Sleeping Princess."

We find in Tchaikovsky's multi-genre interpretation a evolving romance that forms a lyrical poem due to symphony, a musical thematic passage. In Rubinstein's lyrical cycle "Persian Songs," we can see images and methods of the East. Kyui, on the other hand, described romances in the form of lyrical miniatures.

In romances, form, composition, and musical language are different. In the language of music, it is peasant and city songs, domestic romances, dance genres, romantic songs by Schubert and Schumann, a re-intonation of different types of speech.

Many new and interesting works in the chamberinstrumental genre have been created over the years. These are programmed piano miniatures, nocturnes, romance for instruments, piano cycle. The highest works of this period are reflected in Mussorgsky's cycle for piano "Pictures with exhibitions" and Tchaikovsky's cycle of poems 
CURRENT RESEARCH JOURNAL OF PEDAGOGICS 2(11): 24-31, November

2021 DOI: https://doi.org/10.37547/pedagogics-crjp-02-11-08

ISSN 2767-3278

(C)2021 Master Journals

\section{Crossref do) 8 Google}

Accepted 25th November, 2021 \& Published 30 ${ }^{\text {th }}$ November, 2021

"Seasons", inspired by the works of VA Gartman.

In the works of Borodin and Tchaikovsky, the string quartet genre gained great popularity.

In the development of all genres of this period, musical thinking is characterized by symphony, intimacy and interdependence of genres. The latter idea is especially true of the cantataoratorical genres.

The genre of cantata and oratorio is not typical of this period, but the features of oratorio have penetrated deeply into Russian opera, reflected in the scenes for many choirs. There was a closeness between the genres of opera and symphony. Especially in Tchaikovsky's work; chamber-vocal genres and opera interacted with each other. Romances and songs were impressively reflected in the theater.

In the second half of the 19th century, Russian composers went their separate ways. They debated the questions that arose: separately on the path of genres, on national traditions and on the traditions of the past, on the richness of modern events.

In 1870-1880 a new direction in Russian music began. Tchaikovsky's work was more intense than that of the next generation of composers. Rimsky-Korsakov's work was a period of maturity, while Borodin's work lasted until 1887. He continued work on the opera "Prince Igor". In 1880 he wrote a symphonic painting "In Central Asia", in 1881 he wrote a symphony for two quartets "On the shores of the Far Homeland".

During these years, young composers A.K.Glazunov, A.K.Lyadov, S.I.Taneev, A.S.Arensky, V.S.Kalinnikov, M.M.IppolitovIvanov grew up. Their creative path was associated with the next decade. A.K. Glazunov, S.I. Taneev, A.K. Lyadov made a significant contribution to the history of Russian music.

From the early 1990s, young composers began to appear again. AN Skryabin, SV Rakhmaninov are among them. Well, what changes have taken place in the work of composers during this period.First, the theme of tragedy grew, a trend that is evident in Tchaikovsky's work. Second, humanity's belief that beauty is invincible power has increased. We see this in Rimsky-Korsakov's symphonic suite "Shahrizoda", the suite "Spanish capricchio", the opera "The Night Before Christmas"; and it can beseen inTchaikovsky's ballet "Sleeping Beauty", the opera "Iolanta", Glazunov's fourth symphony, Taneev's music.The third is to avoid a deep social problem. Separate genres change function and comparisons.

Only Tchaikovsky constantly expanded his subject to include operas such as The Mermaid of Orleans (1879), Mazepa (1883), Cherevichki (1887), "The Enchantress", (1887), and "The Queen of Spades" (1890). continued. His last opera, Iolanta, was written in 1891.

In the mid-1890s, SI Taneev wrote the opera "Orestea" with an ancient plot in an oratorical style.

During these years, small-scale operas also appeared. These include Tchaikovsky's Iolanta and Rachmaninoff's Aleko. It was during this period that interest in the cantata arose. Tchaikovsky's cantata "Moscow" and Taneev's cantata "Ioann Damaskin" are examples.

In the 1880s, quartet performance played a major role.In 1880-1890 a new development of Russian art began.Separate Russian Music Universities have been established in different cities. Russian symphonic concerts organized by Belyaev are one of the important foundations of Russian music's popularity. A philharmonic committee formed by pianist and conductor T.A. Shostakovsky appeared in Moscow and St. Petersburg. A musical drama school was opened under the Philharmonic Committee.A private opera house was opened by Mamontov, an enthusiastic person and a master of arts. 
CURRENT RESEARCH JOURNAL OF PEDAGOGICS 2(11): 24-31, November

2021 DOI: https://doi.org/10.37547/pedagogics-crjp-02-11-08

ISSN 2767-3278

(C)2021 Master Journals

\section{Crossref doi) 81 Google}

Accepted 25th November, 2021 \& Published 30 ${ }^{\text {th }}$ November, 2021

Mamontov focused on Russian operas without punitive scenes. Here the famous N.I.ZabelaVrubel and the great singer F.Shalyapin sang. S.V.Rakhmaninov began his conducting career at the Opera House. The great artists I.E. Repin, N.A.Korovin, M.A.Vrubel, V.A.Serov, V.M.Vasnetsov worked in the theater.

The great conductor and composer E.F.Napravnik made a great contribution to the achievement of the highest visual level of Russian opera in the early nineteenth and early twentieth centuries. He stood in front of the conductor's panel of the Mariinsky Theater for more than half a century.

In the first half of the 1890s, N.F.Findeyzen, a researcher and critic of Russian music culture, founded a new music magazine, the Russian Music Newspaper, in St. Petersburg.

Tchaikovsky wrote The Sleeping Beauty» in 1889 and «The nutcracker» in 1891. These works show the conflict of the individual and society with great force. Tchaikovsky's "Pikovaya dama" is the pinnacle of opera in the genre of psychological tragedy. The symphonic thinking of the composer in this opera music led to his sixth symphony, written in 1890.

The importance of polyphony in the music of this period (in the works of S.I.Taneev), as well as in orchestration and harmony, increases the variety of colorful and various phonetic beginnings (in the work of N.A. Rimsky-Korsakov).

Composers of the late XIX and early XX centuries created Russian music N.A.Rimsky-Korsakov (last years of his work), A.K.Glazunov, S.I.Taneev, A.K.Lyadov. During these years, the work of A.N.Scriabin and S.V.Rakhmaninov reached the level of maturity, and the name of the composer N.K.Metner became known.

\section{RefERENCES}

1. Ветлугина Н.А., Кенеман А.В. Теория и методика музыкального воспитания в детском саду. -М.: «Просвещение». 1983.

2. Ветлугина Н.А. и др. Методика музыкального воспитания в детском саду. -М.: «Просвещение». 1989.

3. Воспитание музыкального слуха. Сб. статьей. -М., 1977. 19. Гудкова Е.А., Васильева А.Б. Ашула дарслиги методикаси. -Т.: «Ўқитувчи». 1973.

4. Дмитриева Н.Г., Черноиваненко О. Методика музыкального воспитания в школе. -М.,1989. Ветлугина Н.А., Кенеман А.В. Теория и методика музыкального воспитания в детском саду. -М.: «Просвещение». 1983.

5. Yunusov, G. X., Juraev, I., \& Ahmedov, R. The European Journal of Arts, Issue $1 / 2020$.

6. Yunusov, G., Juraev, I., \& Ahmedov, R. (2020). A look at the regional seasonal folklore and their origin. The role and importance of folklore in the development of dance art. European journal of arts, (1), 121-124.

7. Yunusov, G. Y., Parpiev, A., \& Ernazarov, Z. (2021). A look at samples of uzbek folklore. ACADEMICIA: An International Multidisciplinary Research Journal, 11(5), 9-14.

8. Болтабоева, У., \& Дехқонов, Р. (2021). Хаётийлик ва хаққонийлик драматик acap, режиссура, актёрлик махорати асоси. Oriental art and culture, 2(3), 134141.

9. Dadaboev, Y., \& Dehqonov, R. Hordo Structures in Central Asian Architecture.

10. Талабоев, А. Н. (2019). Ўзбек миллий анъанавий ижрочилик санъатида махаллий услублар. Перекрёсток 
CURRENT RESEARCH JOURNAL OF PEDAGOGICS 2(11): 24-31, November

2021 DOI: https://doi.org/10.37547/pedagogics-crjp-02-11-08

ISSN 2767-3278

(C)2021 Master Journals

Crossref do) 81 Google

Accepted 25th November, 2021 \& Published 30 ${ }^{\text {th }}$ November, 2021

культуры, 1(4).

11. Ўғли, х. И. Т. (2020). Ўзбек солиқ терминларининг аффиксация усули билан ясалиши. Oriental art and culture, (v).

12. Ўғли, х. И. Т. (2020). Тилшуносликда солиқ-божхона терминологиясининг тадқиқи. Oriental art and culture, (v).

13. Ismoilova, n., \& habibjonov, i. (2021). Kitob va kitobxonlik-inson manaviyatining kozgusi. Oriental art and culture, 2(1), 159166.

14. Normatova, M., \& Ikromjon, X. (2021). "Qutadg'u bilig" ikki jahonni tutishga ochuvchi yo'l. Oriental Art and Culture, (6).

15. Хабибжонов, И. Т. ў. (2021). СОЛИқБОЖХОНА ТЕРМИНОЛОГИЯСИДА дублетлик ВА УНИ ТАРТИБГА СОЛИШ МАСАЛАЛАРИ. Scientific progress, 1(6), 842-846.

16. Ismoilova, N., \& Habibjonov, I. (2021). KITOB VA KITOBXONLIK-INSON MANAVIYATINING KOZGUSI. Oriental Art and Culture, 2(1), 159-166.

17. Habibjonov, I. (2020). Syntactic design of uzbek tax and customs terminology. Journal of Advanced Research in Dynamical and Control Systems, 12(2), 2910-2915.

18. Oglu, H. I. T. (2020). Formation of uzbek tax and customs terms (on the example of materials on the history of language). ACADEMICIA: AN INTERNATIONAL MULTIDISCIPLINARY RESEARCH JOURNAL, 10(12), 1308-1313.

19. Рўзиева, Г., \& Хабибжонов, И. (2021). САДР ЗИЁ КУТУБХОНАСИ. Oriental Art and Culture, (6).

20. Қурбонова, М. (2021). АЁЛЛАР
САНЪАТИ: КЕЧА ВА БУГУН. Oriental Art and Culture, 2(3), 62-75.

21. Турсунов, Б. (2020). ЧОЛҒУ ИЖРОЧИЛИГИ ТАРИХИГА БИР НАЗАР. Oriental Art and Culture, (V).

22. Ғофурова, Б. (2020). АКТЁРНИНГ НУТҚИНИ ТАКОМИЛЛАШТИРИШДА ИННОВАЦИОН ТЕХНОЛОГИЯЛАРНИНГ АХАМИЯТИ. Oriental Art and Culture, (V).

23. Парпиев, А. (2021). ЖАДИДЧИ ОБИДЖОН МАХМУДОВНИНГ ФАОЛИЯТИДАГИ ЯНГИ ҚИРРАЛАР. Oriental Art and Culture, (6).

24. Мадалиев, А. (2021). ҚЎҒИРЧОҚ ТЕАТРИ ТАРИХИГА НАЗАР. Oriental Art and Culture, 2(3), 125-133.

25. Мадалиев, А. (2021). ҚЎҒИРЧОҚ ТЕАТРИ АКТЁРИНИНГ ПЛАСТИК ИМКОНИЯТЛАРИ. Oriental Art and Culture, (7), 49-57.

26. Мадалиев, А. (2021). НОДАВЛАТ ҚЎҒИРЧОҚ ТЕАТРЛАРИДА АКТЁРЛИК САНЪАТИ МАСАЛАЛАРИ. Oriental Art and Culture, (7), 37-48.

27. Омоновна, С. Х. (2021). МАДАНИЯТ ВА МАЪНАВИЯТ МАСАЛАЛАРИДА ТАРИХИЙ ИЛДИЗЛАР ИЗЛАРИ. Oriental Art and Culture, (7), 244-253.

28. Омоновна, С. Х. (2021). ГЛОБАЛЛАШУВ ЖАРАЁНИДА АХБОРОТ ОҚИМИНИНГ ЁШЛАР МАЪНАВИЯТИГА ТАЪСИРИ ХУСУСИДА. Oriental Art and Culture, (7), 217-224.

29. Омоновна, Х. С. (2020). ТАРИХИЙ ҚЎЛЁЗМА МАНБАЛАРНИ КОНСЕРВАТЦИЯ-РЕСТАВРАЦИЯ ҚИЛИШ ЖАРАЁНЛАРИ ХУСУСИДА. Oriental Art and Culture, (V).

30. Омоновна, С. Х. (2019). Агар бола сизни 
CURRENT RESEARCH JOURNAL OF PEDAGOGICS 2(11): 24-31, November

2021 DOI: https://doi.org/10.37547/pedagogics-crjp-02-11-08

ISSN 2767-3278

(C)2021 Master Journals

Crossref do) 81 Google

Accepted $25^{\text {th }}$ November, 2021 \& Published $30^{\text {th }}$ November, 2021

«Эшитмаса»... Современное образование (Узбекистан), (4 (77)), 58-63.

31. Омоновна, С. Х. (2018). Ўқувчилар тарбиясини шакллантиришда отаоналарга педагогик билим бериш тизимининг ахамияти. Современное образование (Узбекистан), (5).

32. Омоновна, С. Х. (2018). «Бебош бола» синдроми ёхуд нега болалар асабийлашади?. Современное образование (Узбекистан), (11).

33. Солиева, Х. О. (2018). ВЗГЛЯДЫ ИБН СИНО НА МЕДИЦИНСКОЕ ВОСПИТАНИЕ МОЛОДЁЖИ. Актуальные научные исследования в современном мире, (56), 56-60.

34. Shermatova, X. (2020). MUSIQA NAZARIYASINING O'ZIGA XOS XUSUSIYATLARI. Oriental Art and Culture, (V).

35. ШЕРМАТОВА, Х. К. (2015). Народная музыка как средство музыкальноэстетического воспитания школьников. In Юность и Знания-Гарантия Успеха2015 (pp. 318-316).

36. Шерматова, Х. К. (2020). ФОРМИРОВАНИЕ МУЗЫКАЛЬНОЙ КУЛЬТУРЫ МОЛОДЁЖИ. ПроблемЫ современной науки и образования, (121 (157)), 117-119.

37. Shermatova, X. (2020). MUSIQA NAZARIYASINING O'ZIGA XOS XUSUSIYATLARI. Oriental Art and Culture, (V).

38. Пўлатов, Р. (2020). «МИРЗО УЛУҒБЕК» ТРАГЕДИЯСИНИНГ ЯРАТИЛИШИ ТАРИХИ. Oriental Art and Culture, (V).

39. Ismoilova, M. (2020). CHOLG'U IJROCHILIGIDA NOTAGA QARAB IJRO QILISH. Oriental Art and Culture, (V).
40. Болтабоева, У. (2021). БЎЛАЖАК АКТЁРЛАРНИ ТАРБИЯЛАШДА ПЕДАГОГИК ЁНДАШУВЛАР. Oriental Art and Culture, 2(3), 88-98.

41. Болтабоева, У., \& Дехқонов, Р. (2021). ХАЁТИЙЛИК ВА ХАҚҚОНИЙЛИК ДРАМАТИК АСАР, РЕЖИССУРА, АКТЁРЛИК МАХОРАТИ АСОСИ. Oriental Art and Culture, 2(3), 134-141.

42. Boltaboeva, U., \& Xalilov, Y. (2021). TEATR SAN'ATINING 0 'ZIGA XOS XUSUSIYATLARI. Oriental Art and Culture, 2(3), 40-48.

43. Boltaboyeva, U., \& Yu, K. (2021). THE DIRECTOR'S WORK ON MONOLOGUE AND MISE-EN-SCENES. CURRENT RESEARCH JOURNAL OF PEDAGOGICS (2767-3278), 2(10), 71-77.

44. Хатамова, Ё., \& Болтабоева, У. (2019). Нутқ техникасини такомиллаштиришда халқ оғзаки ижодидан фойдаланиш усуллари. Oriental Art and Culture, (IV (1)), 50-52.

45. У Смонов, Ш. Ю. (2021). РЕЖИССЁРНИНГ РАССОМ БИЛАН ИШЛАШИ. Oriental Art and Culture, (6).

46. Boltaboeva, U., Abdunazarov, Z., \& Usmonov, S. (2021). The balance of language and speech in the Uzbek theater. ASIAN JOURNAL OF MULTIDIMENSIONAL RESEARCH, 10(4), 788-792.

47. Abdunazarov, Z. (2021). HAMZA HAKIMZODA NIYOZIY DRAMATURGIYASI. Oriental Art and Culture, 2(3), 170-178.

48. Хайдаров, А. (2021). ЁШЛАРИМИЗНИНГ ЭСТЕТИК БАРКАМОЛ БЎЛИБ УЛҒАЙИШИДА ЎЗБЕК ХАЛҚ ОҒЗАКИ ИЖОДИ НАМУНАЛАРИНИНГ ЎРНИ. Oriental Art and Culture, (6).

49. Асқарова, М. (2021). АДАБИЙ 
CURRENT RESEARCH JOURNAL OF PEDAGOGICS 2(11): 24-31, November

2021 DOI: https://doi.org/10.37547/pedagogics-crjp-02-11-08

ISSN 2767-3278

(C)2021 Master Journals

Crossref dof 8 Google

Accepted 25th November, 2021 \& Published 30th November, 2021

ЖАРАЁННИНГ ЗУККО ТАДҚИҚОТЧИСИ.

Oriental Art and Culture, (7), 209-216.

50. Askarova, M. (2020). Homil yakubov's views on navoi studies. ACADEMICIA: AN INTERNATIONAL MULTIDISCIPLINARY RESEARCH JOURNAL, 10(12), 788-792.

51. Askarova, M. (2021). Homil Yakubov's views on Oybek lyrics. ACADEMICIA: An International Multidisciplinary Research Journal, 11(3), 2412-2415 